\section{An erosion of eminence?}

Colin Norman reports from Washington on a document that examines the strengths and weaknesses in American science

American pre-eminence in most areas of science and technology is gradually being eroded, largely because inflation has been eating into funds for research and development in the United States and many other countries have been ploughing large resources into their own science programmes for the past few years. That conclusion emerges from a detailed statistical portrait of American science from 1960 to 1974 published last month by the National Science Board, a committee of eminent scientists which directs the policies of the National Science Foundation.

A cautiously worded document which studiously avoids drawing many conclusions, it attempts to pinpoint strengths and weaknesses in American science and to analyse long-term trends. It covers a vast range of data, including funding levels for research and development, employment statistics, rates of innovation, output of scientific literature and the average number of citations per research paper.

Taken on its own, any one of those indicators probably doesn't mean very much, but together they seem to show a consistent trend-the quality and quantity of American science in relation to that of other countries appears to be headed downwards. The trend, in fact, is so consistent that early drafts of the report are said to have played an important role in securing a large increase for science and technology in the budget announced by President Ford last January. That budget would increase support for research and development by about $11 \%$, while total federal expenditures would only grow by about $5.5 \%$.

\section{Shrinking funds}

The clearest and most striking trend brought out in the report is that government funds for research and development have been shrinking steadily in terms of purchasing power since 1968. Support for basic research dwindled by $13 \%$, between 1968 and 1974, while expenditures per scientist dropped by a staggering $30 \%$ over the same period.

In an attempt to analyse trends in the United States in relation to those in other countries, the report brings out the fact that only two countries- the United States and France-have shown a long-term decline in the proportion of gross national product spent on science and technology, and the United States is alone in showing a steady decline in the number of scientists and engineers employed in research and development.

Though there have been some significant changes in the pattern of government support for research and development, the report shows that the United States devotes a larger share of its research budget to defence (about $50 \%$ ) than other countries do. Over the past seven years, however, the share devoted to space science and technology has dwindled, while that devoted to other areas of science has increased.

It is difficult to measure the effect of shrinking support on the overall quality and productivity of American science, but several indicators suggest that the cuts are beginning to show some impact. One measure suggests that the proportion of research papers in several ficlds of science produced by Americans has reached a plateau; in some cases it has declined. The fields chosen are chemistry, physics, engineering, psychology, molecular biology, systematic biology, and mathematics; in all except chemistry and mathematics, the US still produces the largest share of the world's literature, however.

\section{UK ranks high}

As for the quality of research, the report indicates that in every field, research papers produced in the United States are cited on average more often than those produced elsewhere. According to that criterion, papers produced in the United Kingdom rank second in the fields of clinical medicine, biology, and carth and space science, while the UK ranks third in chemistry, physics and engineering. The report does not attempt to analyse whether there are any long-tcrm changes in ranking.

As for technological invention and innovation, some indicators again suggest that American pre-eminence is being eroded by gains in other countries. One measure, the so-called 'patent balance', which relates the number of patents granted to nationals with those granted to foreigners in each country, has been dropping steadily in the United States since 1966. Over the period 1966 to 1973 , the number of foreign patents granted in the United states increased by $65 \%$, reaching $30 \%$ of the total granted in
1973. That, the report notes, "suggests that the number of patentable ideas of international merit has been growing at a greater rate in other countries than the United States".

Another striking example of that trend shows up in an analysis of rates of innovation. According to a study of some 500 innovations in various areas of science and technology, the US was producing about $80 \%$ of the world's innovations in the mid $1950 \mathrm{~s}$. By the mid-1960s, the US share had shrunk to about $50 \%$, and although there has been a slight increase since, it has been caused more by a decline in the UK's share than by an improvement in the US position. (The share of technological innovations produced in Britain declined from $25 \%$ in 1965 to about $15 \%$ in 1973.)

The only indicator which seems to buck the trend of declining US leadership in science and technology is a measure of the balance of trade in high technology products. From 1960 to 1970 , the US balance of payments in such products climbed steadily from about $\$ 6,000$ million to about $\$ 12,000$ million, but between 1972 and 1974 , it suddenly jumped to $\$ 25,000$ million a year.

\section{Basic research affected}

The area most severely affected by declining support in the United States is basic research. In terms of constant dollars, federal support for such research shrunk by some $13 \%$ between 1968 and 1974. Physical sciences were the hardest hit, declining by $25 \%$, chiefly because of reductions in the space programme. Those declines have had considerable impact in the universities.

The report notes, for example, that the universities went through a period of rapid expansion until the early 1970 s, with faculty numbers in science departments increasing by more than $60 \%$ between 1965 and 1972. But, because of declining funds for research, the academic job market has become relatively depressed recently. The result is that the proportion of faculty with tenure has increased from 47 to $65 \%$, and the proportion of young doctoral faculty in postgraduate science and engincering departments declined from $42 \%$ in 1968 to $28 \%$ in 1974 . The median age of faculty members consequently increased from 41 to 44 .

Many of the trends and conclusions brought out in the report are hedged with caveats and cautions. The National Science Board hopes to refine some of the measures, and produce an updated report in a couple of years time, however. 